\title{
摩砕によるリン酸ミコバルト八水和物の メカノケミカル変化
}

戸田善朝*・橋本甲四郎* ・ 荒井康夫**

\begin{abstract}
要
旨

コバルト・ピンクとして，またコバルト・バイオレットディープ（リン酸三コバルト無水物，以下，無水物と 表す) の原料として知られているリン酸三コバルト八水和物（以下，八水和物と表す）の摩砕による粒子性状の 変化を調べた。その結果, 八水和物（板状結晶, 大きさ $3 \times 10 \mu \mathrm{m}$ ) は摩砕により容易に脱水し, 摩砕 20 時間 後にはX線的に無定形の無水物になった。この摩砕物は電子顕微鏡で観察すると粒子径約 $0.2 \mu \mathrm{m}$ のほぼ均一な 球状粒子の集合体であった。色相は, 摩砕時間の增加とともに 6 配位 $\mathrm{Co}^{2+}$ 特有の淡紅色から 4 配位 $\mathrm{Co}^{2+}$ 特有 の青紫色に变化した。この摩砕物を純水に入れると水和して発熱し，すみやかに微細な八水和物（粒子径, 約 0.2 $\mu \mathrm{m})$ となることを認めた。これら板状の原試料と球状のその摩砕物は, 加熱しても500 $\mathrm{C}$ までは粒子の形状が 変化しないので外形と色相との関係を比較した。また, 摩砕物の DTA 曲線には再結晶化による発熱ピークが現 われるが，そのピーク温度は試料の摩砕効率によって著しく変化することがわかった。
\end{abstract}

\section{1. 緒言}

近年, 固体物質の粉砕において, その機械的エネルギ 一によって粉䂶物に物理化学的な変化が起こる現象, す なわちメカノケミストリーに関する研究 ${ }^{1,2)}$ が活発に行 なわれている。摩砕により固体が微細化されると粒子径 の減少, 比表面積の増大, 応力による格子の変形, 内部 エネルギー, 表面エネルギーの増大による転移 ${ }^{31}$, 脱水 ${ }^{4)}$ など数多くの現象が生じる。顔料の製造においても粉砕 峐重要な単位操作で, 特に光学的性質を向上させるら党 に怙いて，粉砕により粒子の形状や粒子径などがどのよ らに変化するかを調べることは大切である。このような 観点から, 著者らは硫セレン化カドミウム赤色系無機顔 料の色相と機戌的力によって生じる格子ひずみとの関係 飞ついて報告らした。

コバルト系紫色顔料には, 従来から知られているコバ ルト・バイオンット・ディープの他に, リン酸アンモニ

昭和 54.12.6 受理

* 千葉工業大学工業化学科

千葉県習志野市津田沼 2-17-1（干275）

** 日本大学理工学部工業化学科

東京都千代田区神田駿河台（干101）
ウムコン゙ルト一水和物6)やリン酸りチウムコバルト7)な どがあるが，本報ではコバルト・バイオレット・ディー プの原料であり, かつコバルト・ピンクとして古くから 知られているにもかかわらず，粒子性状に関する研究例 の少ない八水和物を対象として, 摩砕による脱水, 色相 変化, 摩砕物の水和性について検討した。

\section{2. 実験方 法}

\section{1 試 料}

原料である八水和物はつぎのように調製した。 0.2 $\mathrm{mol} / l$ の硫酸コバルト水溶液 $300 \mathrm{~m} l$ に $0.2 \mathrm{~mol} / l$ のリ 酸二水素ナトリウム水溶液 $600 \mathrm{~m} l$ をミキサー (National MX-150S, 容量 $1.8 l, 9000$ r.p.m.) でかくはんし ながら加え, 室温で 2 時間静置した。反応直後は青色の 沈殿であるが，このけん濁液を 30 分間くらいかくはん すると淡紅色の八水和物となる。沈殿は沪過, 水洗し, $50^{\circ} \mathrm{C}$ で 2 昼夜乾燥した。使用した試薬はいずれもキシダ 化学製一級試薬である。

\section{2 摩 砕}

摩研は石川式めのう摩砕機 $(\phi 120 \mathrm{~mm} \times 30 \mathrm{~mm}, 130$ r.p. m., 加圧 $6 \sim 8.5 \mathrm{~kg} / \mathrm{cm}^{2}$ ) を使用して大気中, 所定 時間行なった。試料量は $0.2 \sim 5.0 \mathrm{~g}$ とした。摩砕後の試 
料は，ただちにシリカゲル乾燥剤入りのデシケータに入 れ，減圧状態で保存し，できるかぎり早く測定に用いた。

\section{3 測 色}

測色は島津(株)製ハーデー型自記分光光度計 RC-III 型を使用して行ない，CIE 表色法で比較した。標準物質 は試薬特級の酸化マグネシウムを粉末庄着して用いた。 測色試片は，まず試料約 $1 \mathrm{~g}$ に半練りポピーオイル約 $0.3 \mathrm{~g}$, 液状ポピーオイル 3 滴を加えてフーバーマーラ 一で, 50 回転を 6 回くりか觉して練りあわせ，黒紙上に ドクターブレードで下地の見党ない厚さ $100 \mu \mathrm{m}$ 均一に 㙦り付けたものを用いた。

\section{4 電子顕微鏡観察}

粒子の形状, 凝集性などの観察は, 日本電子(株)製電 子顕微鏡装置 JEM-7 型を使用して行なった。検鏡試料 は，ホルムバール支持膜をはったメッシュに試料を分散 させ，乾燥して用いた。

\section{5 熱分析}

試料の熱重量分析 (TG) は，島津 (株) 製 Recording Micro Balance RMB-50を使用して測定した。装置はパ イレックス製, 完全気密式である。試料容器は白金るつ ぼを用い, 試料量は約 $30 \mathrm{mg}$ とした。また, 示差熱分析 (DTA) は理学電機(株)製の装置を使用して測定した。 試料容器は石英製, 試料量は約 $280 \mathrm{mg}$, 標準物質は $\alpha$ $\mathrm{Al}_{2} \mathrm{O}_{3}$ である。熱分析に拈ける昇温速度は, SCR 電源お よびプログラム調節器 Chino-NP-163-2 とより制御し た。

\section{6 熱 量}

メカノケミカル脱水を起こした摩砕物は，水中に入れ ると水和熱を発生するので, その熱量を(株)応用電気研 究所製 CM-204 H 型微少熱量計を用いて測定した。 乾燥試料約 $1.8 \mathrm{~g}$ をガラス製アンプルに入れて, $10^{-5}$ Torr まで脱ガスし， 真空下でアンプルをシールして $40^{\circ} \mathrm{C}$ で測定した。

\section{$2.7 \mathrm{X}$ 線回折}

X線回折の測定は, 理学電機(株)製X線回折装置を使 用して行なった。測定条件は, $\mathrm{CuK} \alpha, \mathrm{Ni}$ Filter， 30 $\mathrm{kV}-8 \mathrm{~mA}$ ，走查速度 $1 \% \mathrm{~min}$ である。

\section{8 比表面積}

比表面積の測定は, (株)蔵持科学製 BET 装置を使用 して行なった。測定条件は, 吸着ガス: 窒素, 吸着温 度 : $-183^{\circ} \mathrm{C}$, 真空度 : $10^{-5}$ Torr である。

\section{3. 結果および考察}

\section{1 八水和物の粒子性状}

硫酸コバルト水溶液にリン酸水素ニナトリウム水溶液

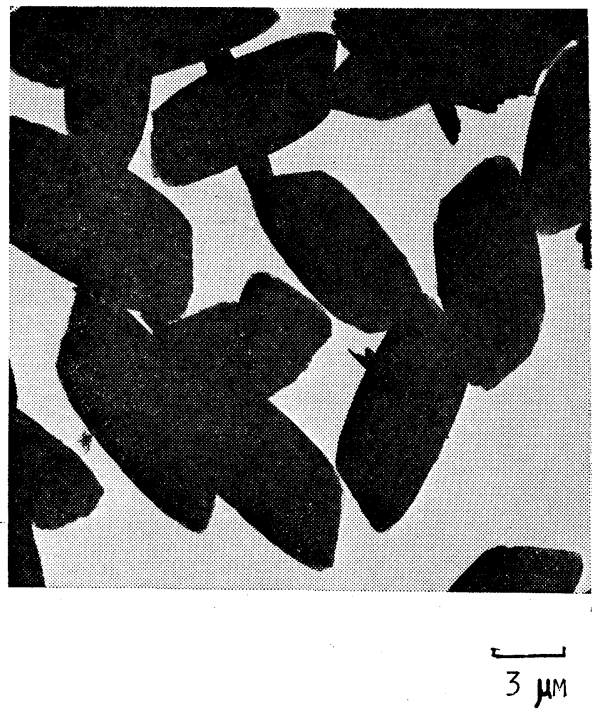

Fig. 1. Electron micrograph of $\mathrm{CO}_{3}\left(\mathrm{PO}_{4}\right)_{2} \cdot 8 \mathrm{H}_{2} \mathrm{O}$

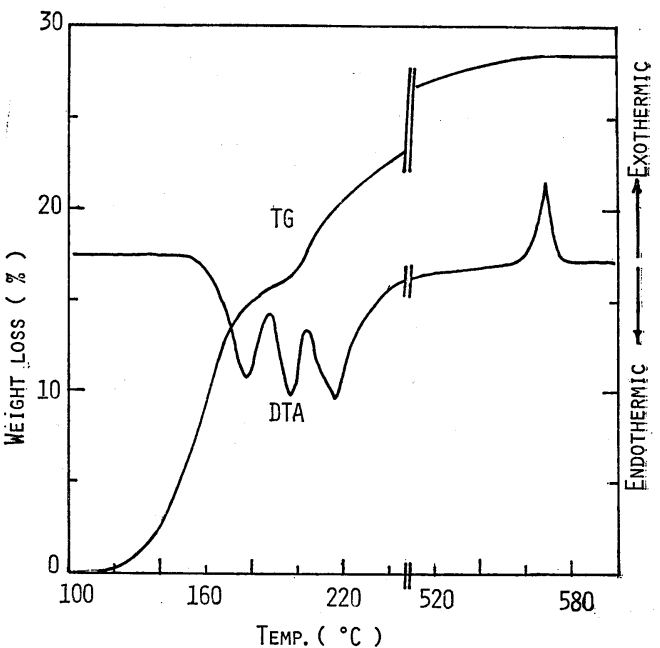

Fig. 2. TG-DTA curve of $\mathrm{Co}_{3}\left(\mathrm{PO}_{4}\right)_{2} \cdot 8 \mathrm{H}_{2} \mathrm{O}$ in air (Heating rate $3.3^{\circ} \mathrm{C} / \mathrm{min}$ )

をかくはんしながら加えると，まずX線的に非晶質の青 色沈殿 $\left(600^{\circ} \mathrm{C}\right.$ に拈ける脱水量 $\left.15.3 \%\right)$ ができる。この けん濁液をさらにかくはんすると，青色沈殿は淡紅色の 八水和物（約 $3 \times 10 \mu \mathrm{m}$, 板状結晶）飞変化する（図-1）。 この沈殿物の熱分析結果を図-2 に示した。TG 曲線よ り，八水和物は約 $110^{\circ} \mathrm{C}$ からすみやかに脱水が始まり, 約 $560^{\circ} \mathrm{C}$ で恒量に達する。一方，DTA 曲線では 150 $230^{\circ} \mathrm{C}$ に打いて脱水による 3 つの吸熱ピークが認められ る。これらの吸熱ピークは試料量を約 $50 \mathrm{mg}$ として測 定すると 4 つのピークに分かれ，また 3.2 で示す微細な 不定形八水和物の場合にはそれが 1 つのピークとなるこ とを認めた。このことから，八水和物の脱水による吸熱 


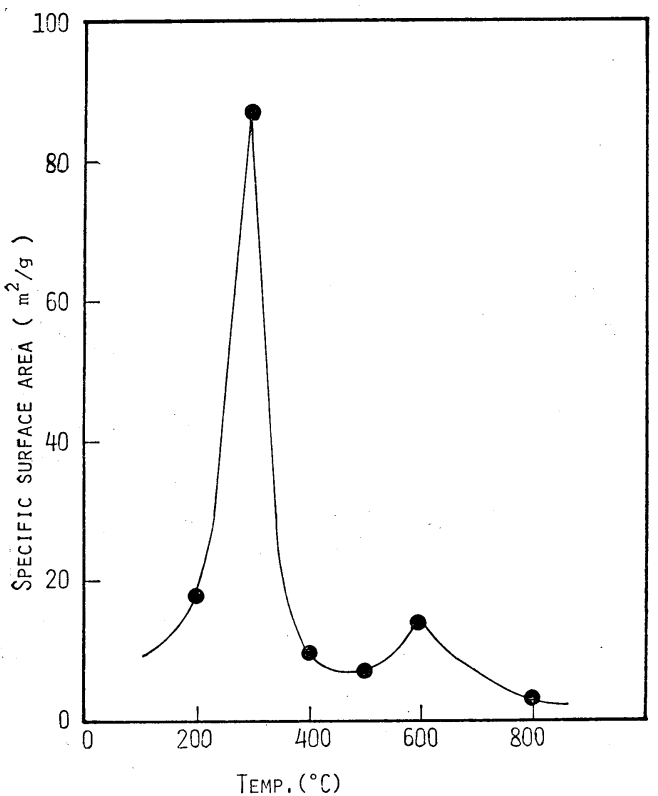

Fig. 3. Specific surface area of heated $\mathrm{Co}_{3}\left(\mathrm{PO}_{4}\right)_{2} \cdot 8 \mathrm{H}_{2} \mathrm{O}$

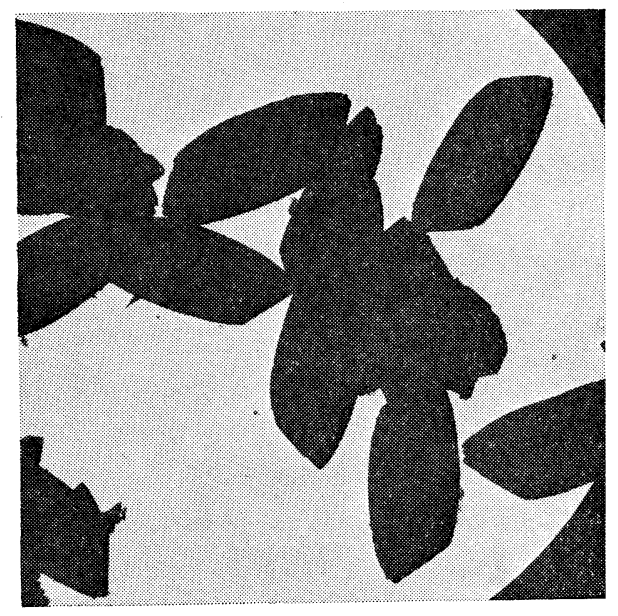

$\overline{3 \mu m}$

Fig. 4. Electron micrograph of $\mathrm{Co}_{3}\left(\mathrm{PO}_{4}\right)_{2} \cdot 8 \mathrm{H}_{2} \mathrm{O}$ heated at $300^{\circ} \mathrm{C}$ for $1.0 \mathrm{hr}$

ピークの形の違いは, 試料粉体のパッキングの状態の違 いや粒子径などの影響によると思われる。

吸熱ピークをすぎた $250^{\circ} \mathrm{C}$ から $550^{\circ} \mathrm{C}$ 間の試料はX 線的に無定形で，色相は主波長が約 $-570.0 \mathrm{~nm}$ の青紫 色であった。また, $570^{\circ} \mathrm{C}$ 付近に発熱ピークが認められ るが，発熱ピークをすぎる無水物（ASTM カード13503) の回折線が認められ，色彩は主波波 $-557.1 \mathrm{~nm}$,

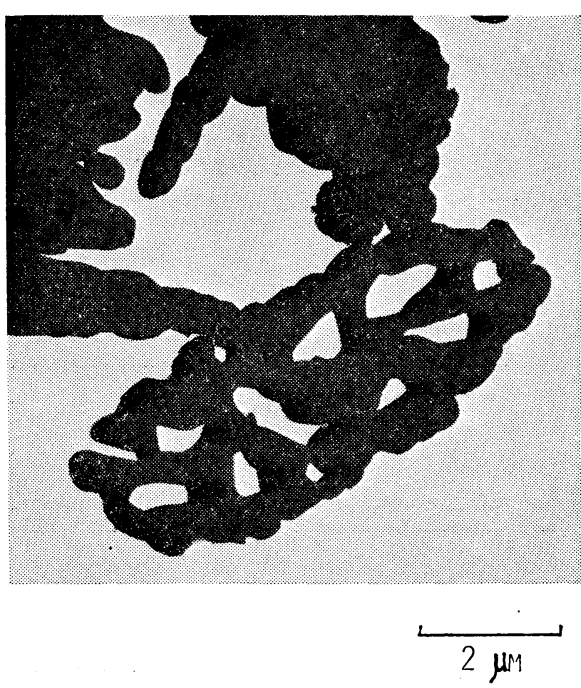

Fig. 5. Electron micrograph of $\mathrm{Co}_{3}\left(\mathrm{PO}_{4}\right)_{2} \cdot 8 \mathrm{H}_{2} \mathrm{O}$ heated at $600^{\circ} \mathrm{C}$ for $0.5 \mathrm{hr}$

明度 $4.3 \%$, 純度 $38.3 \%$ の赤紫色に変化した。無水物 は, $550^{\circ} \mathrm{C}$ くらいまでは母結晶の形がい構造を保ってい た。しかし，焼成温度によって焼成物の比表面積（図-3） は変化し, $300^{\circ} \mathrm{C}$ 焼成物の場合, 電顕写真（図-4）では 粒子の外形に変化は認められないが，比表面積は最大值 $87 \mathrm{~m}^{2} / \mathrm{g}$ を示している。これは脱水により粒子表面に微 細な空孔を生じたためと思われる。このことは $600^{\circ} \mathrm{C}$ 焼 成物の電顕写真（図-15）からも推察できる。

\section{2 八水和物のメカノケミカル脱水と再水和}

八水和物は, 水分子を多く含んでいるので多くの水和 物と同様, 容易にメカノケミカル脱水することが考えら れる。

八水和物を摩砕した（試料量 $5 \mathrm{~g}$ ) もののX線回折図を 図-6に示した。図から，摩砕 4 時間くらいをでは回折線 の相対強度は徐々に低下し, 10 時間摩砕物では $2 \theta=$ 13. $2^{\circ}$ の回折線だけがわずかに認められる。摩碑を 20 時間行なうと，X線的にはほとんど無定形になった。一 般に摩砕を行ならと, 回折線の半価幅は大きくなる場合 が多いが，この試料の場合，半価幅の変化よりもむしろ 回折線の相対強度の低下が目だった。これは八水和物が 摩砕により，かなりすみやかに脱水するためと思われ る。摩砕後の粒子の形状は, 15 分間摩砕で元の外形は ほとんどくずれ，20 時間で約 $0.2 \mu \mathrm{m}$ の球状（図-7）と なり，それ以上の摩砕では二次凝集体を形成した。な 扣, 試料量を約 $0.4 \mathrm{~g}$ 以下として摩砕した場合, 30 分 間摩砕でも X線的には無定形になった。

つぎに, 摩砕により色彩が著しく変化した試料の測色 


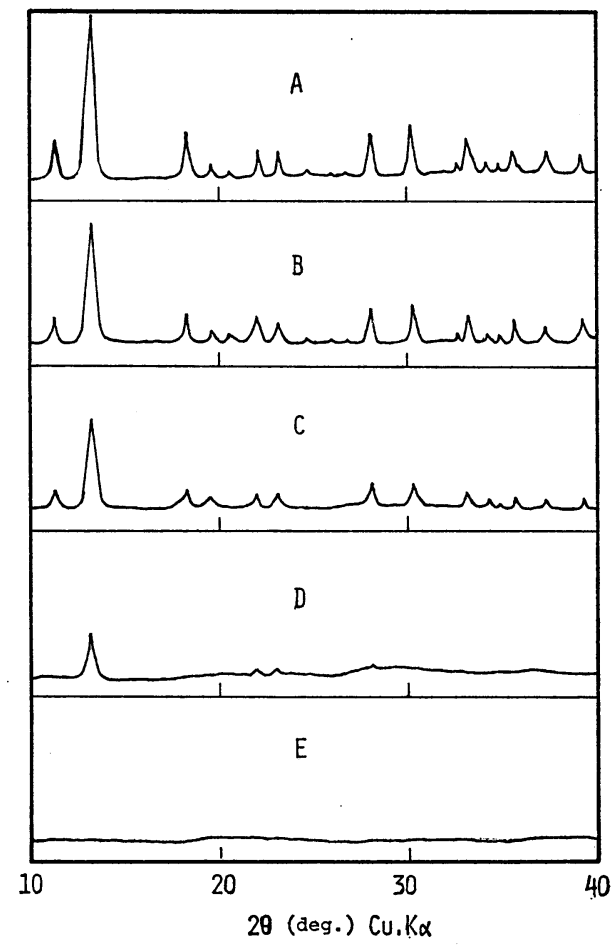

Fig. 6. X-ray diffraction patterns of ground $\mathrm{Co}_{3}\left(\mathrm{PO}_{4}\right)_{2} \cdot 8 \mathrm{H}_{2} \mathrm{O}$

(A) : original, (B) : ground for $1 \mathrm{hr}$,

(C) : ground for $4 \mathrm{hr}$, (D) : ground for $10 \mathrm{hr}$,

(E) : ground for $20 \mathrm{hr}$

(Sample weight $0.5 \mathrm{~g}$ )

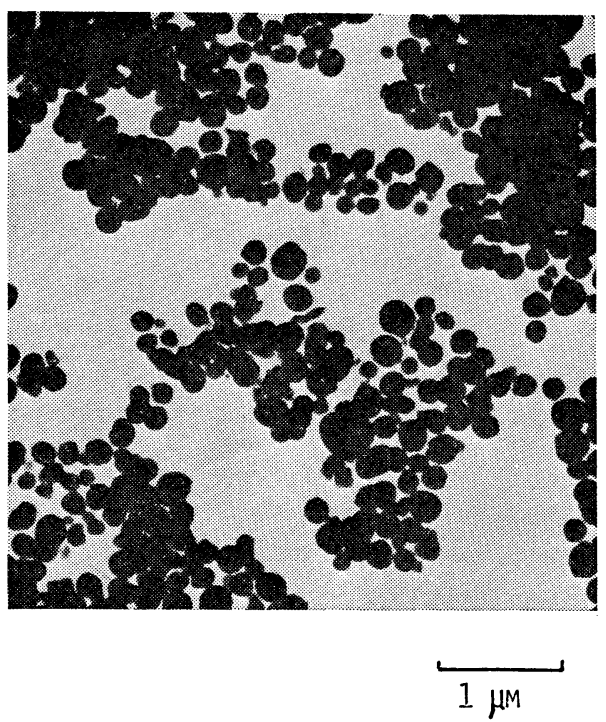

Fig. 7. Electron micrograph of $\mathrm{Co}_{3}\left(\mathrm{PO}_{4}\right)_{2} \cdot 8 \mathrm{H}_{2} \mathrm{O}$ after grinding for $20 \mathrm{hr}$

(Sample weight $5.0 \mathrm{~g}$ )

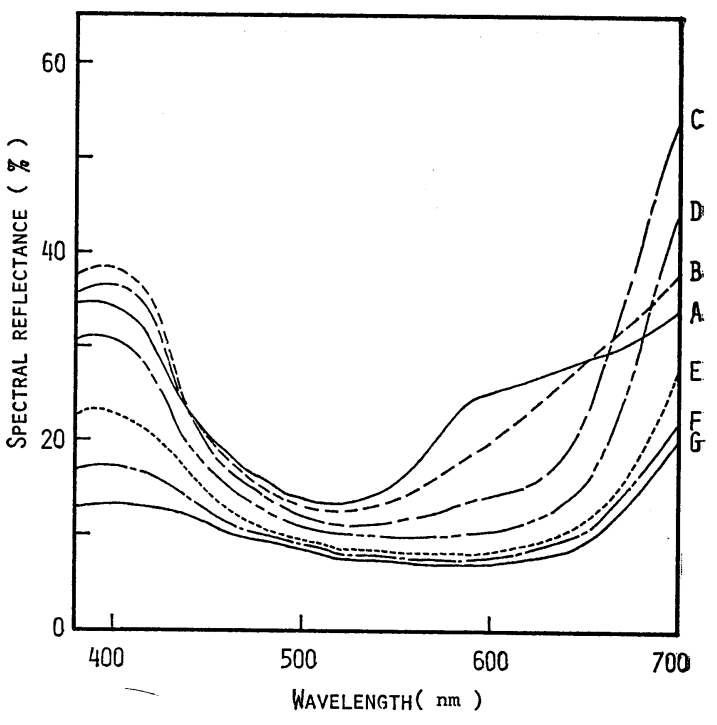

Fig. 8. Spectral reflectance curves of ground $\mathrm{Co}_{3}\left(\mathrm{PO}_{4}\right)_{2} \cdot 8 \mathrm{H}_{2} \mathrm{O}$

(A) : original, (B) : ground for $5 \mathrm{~min}$,

(C) : gronud for $15 \mathrm{~min}$, (D) : ground for $1 \mathrm{hr}$,

(E) : ground for $5 \mathrm{hr}$, (F) : ground for $20 \mathrm{hr}$,

(G) : ground for $50 \mathrm{hr}$ (Sample weight $5.0 \mathrm{~g}$ )

結果を図-8 および表-1 に示した。八水和物の分光反射 率曲線には，この図からは明りょらに読み取れないが, 約 470，490，510 nm に吸収がみられ，さらに $660 \mathrm{~nm}$ 付近にも弱い吸収があり, 緑の部分をカットし, 赤側の 反射と相まって 6 配位 $\mathrm{Co}^{2+}$ 特有の淡紅色を呈している ことを示している。しかし，摩碎が進むと600〜660 nm 付近の吸収が増し， 5 分間摩砕したものは主波長 $545.0 \mathrm{~nm}$ の紫みのうすい赤紫色になった。1 時間摩 砕したものの色彩は, 主波長 $-566.0 \mathrm{~nm}$, 純度 23.8 $\%$ ，明度 $10.5 \%$ の紫みのにぶい青紫色飞変化した。 DuMont ら ${ }^{8)}$ は, コバルトスピネル青色顔料の 4 配位 $\mathrm{Co}^{2+}$ の吸収が, 495, 565, 600, $660 \mathrm{~nm}$ に現れることを 報告している。八水和物の 50 時間摩研物の分光反射率 曲線には, この 4 配位 $\mathrm{Co}^{2+}$ の吸収は明確には認められ ないが，約 $460 〜 680 \mathrm{~nm}$ に幅広い吸収帯が存在してい ること,さらにその色相も紫みのにぶい青色を呈してい ることから,この摩砕物は 4 配位 $\mathrm{Co}^{2+}$ の構造をとって いるものと思われる。

摩砕後の粉末の比表面積は, 摩砕 1 時間で約 $6 \mathrm{~m}^{2} / \mathrm{g}$, 5 時間で約 $15 \mathrm{~m}^{2} / \mathrm{g}$ の最大值をとってメカノケミカル平 衡に達し, 10 時間以上では二次凝集体形成のため約 9 $\mathrm{m}^{2} / \mathrm{g}$ に減少した。

また，図-9 に摩砕した試料の含水量の変化を示した。 
Table 1. Change of colour by grinding of $\mathrm{Co}_{3}\left(\mathrm{PO}_{4}\right)_{2} \cdot 8 \mathrm{H}_{2} \mathrm{O}$

\begin{tabular}{c|r|r|r|r|r|r}
\hline Grinding time & Original & \multicolumn{1}{|c|}{5 min. } & \multicolumn{1}{|c|}{$15 \mathrm{~min}}$. & \multicolumn{1}{|c|}{$1 \mathrm{hr}}$. & \multicolumn{1}{|c}{$10 \mathrm{hr}}$. & \multicolumn{1}{c}{$50 \mathrm{hr}}$. \\
\hline$\lambda d(\mathrm{~nm})$ & -500.2 & -545.0 & -560.8 & -566.0 & -566.7 & -566.5 \\
$\mathrm{Pe}(\%)$ & 29.2 & 24.0 & 26.8 & 23.8 & 15.3 & 10.5 \\
$\mathrm{Y}(\%)$ & 17.4 & 15.7 & 12.9 & 10.5 & 9.5 & 9.4 \\
\hline
\end{tabular}

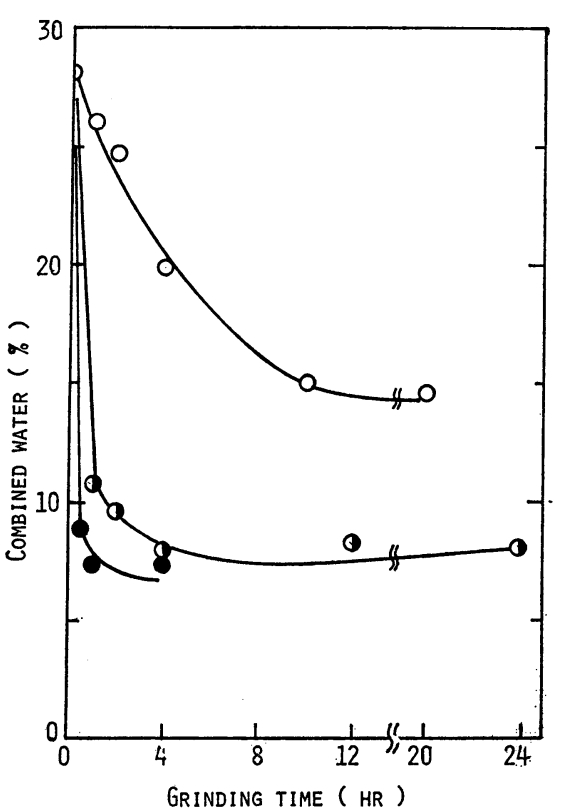

Fig. 9. Dehydration curves of $\mathrm{Co}_{3}\left(\mathrm{PO}_{4}\right)_{2} \cdot 8 \mathrm{H}_{2} \mathrm{O}$ with grinding
$O$ : sample weight $5.0 \mathrm{~g}$
I : sample weight $0.4 \mathrm{~g}$
: sample weight $0.2 \mathrm{~g}$

試料量は，(I) $5.0 \mathrm{~g}$ （II） $0.4 \mathrm{~g}$ （III） $0.2 \mathrm{~g}$ である。 八水和物の結合水は $28.2 \%$ であるが，(I) の場合， 10 時間摩砕で含水量は約 15\% になっていた。しかし, 試 料量の少ない（II) 拈よび（III）の場合は，1時間摩砕 でもそれぞれ約 $11 \%$ ，約 $8 \%$ まで減少した。この八水 和物の摩砕物はX線的に無定形となり, 色彩は不鮮明な 青紫色となった。また, 八水和物を $500^{\circ} \mathrm{C} て ゙$ 焼成した無 水物も X線的に無定形で，色彩もこの摩砕物とよく類似 していることから，八水和物は摩碎によってィカノケミ カル脱水したものと推定できる。な拈, 長時間摩砕した ものでも数\%の含水量が認められるが，これは摩砕を大 気中で行なったため, 吸湿したことによるものと思われ る。

つぎに, 摩砕物の DTA 曲線について比較検討した （図-10，-11）。因には省略するが，摩砤物の脱水による 吸熱ピーク温度は, 摩䂶時間の長い試料ほど低下してい

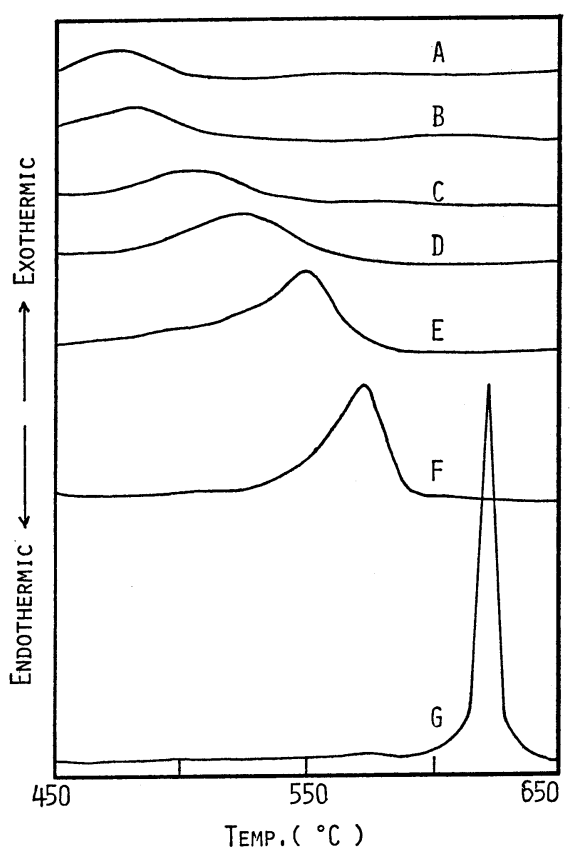

Fig. 10. DTA curves of ground $\mathrm{Co}_{3}\left(\mathrm{PO}_{4}\right)_{2} \cdot 8 \mathrm{H}_{2} \mathrm{O}$

(A): ground for $0.5 \mathrm{hr}$, (B) : ground for $1 \mathrm{hr}$,

(C) : ground for $2 \mathrm{hr}$, (D) : ground for $4 \mathrm{hr}$,

(E) : ground for $6 \mathrm{hr}$, (F) : ground for $12 \mathrm{hr}$,

(G) : ground for $24 \mathrm{hr}$

(Sample weight $0.2 \mathrm{~g}$, heating rate $3.3^{\circ} \mathrm{C} / \mathrm{min}$ )

た。また, 無水物の結晶化のための発熱ピークの温度 は, 摩研時間や試料量が異なると著しく变化している。 すなわち, 発熱ピークの温度は摩哗時間が非常に短い試 料では, 原試料に比べてかなり低く, しかも, 試料量の 少ない場合ほど低い。この温度の低下の理由は, 脱水に よって結晶が気孔性に富み比表面積が大きくなったため である。しかし, さらに摩砕を続けると, そのピークは 高温側へ移動し, その強度も大きくなった。また, 試料 量が少ないものほどピーク温度が高くなっている。これ は, 摩砕効率がよいほど格子ひずみがそれだけ大きくな り, 結晶化のための活性化エネルギーも大きくなるため と考えられる。

摩碎によって得た無水物は, 大気中に放置しておくと 淡紅色に変化するため, この試料の水和性と粒子性状に 


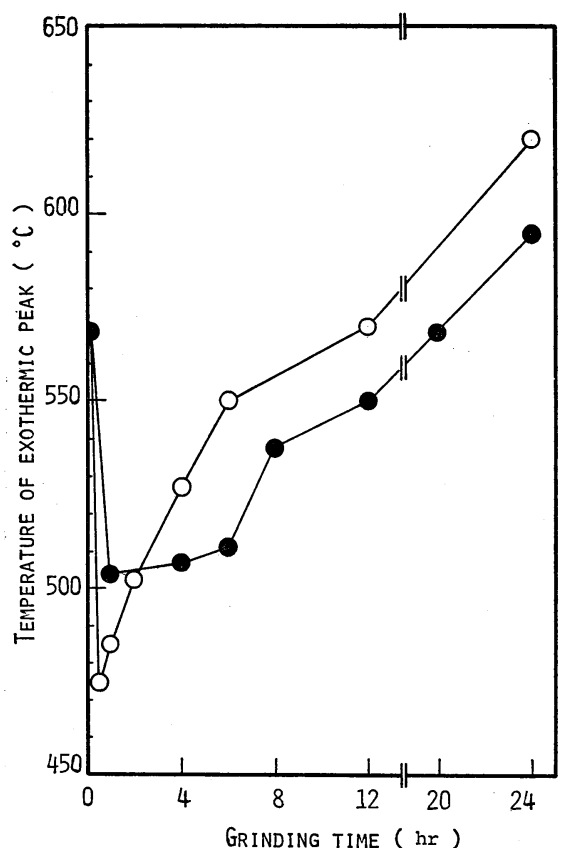

Fig. 11. Change of exothermic temperature of ground $\mathrm{Co}_{3}\left(\mathrm{PO}_{4}\right)_{2} \cdot 8 \mathrm{H}_{2} \mathrm{O}$

: Sample weight $0.4 \mathrm{~g}$ : Sample weight $0.2 \mathrm{~g}$ (Heating rate $3.3^{\circ} \mathrm{C} / \mathrm{min}$ )
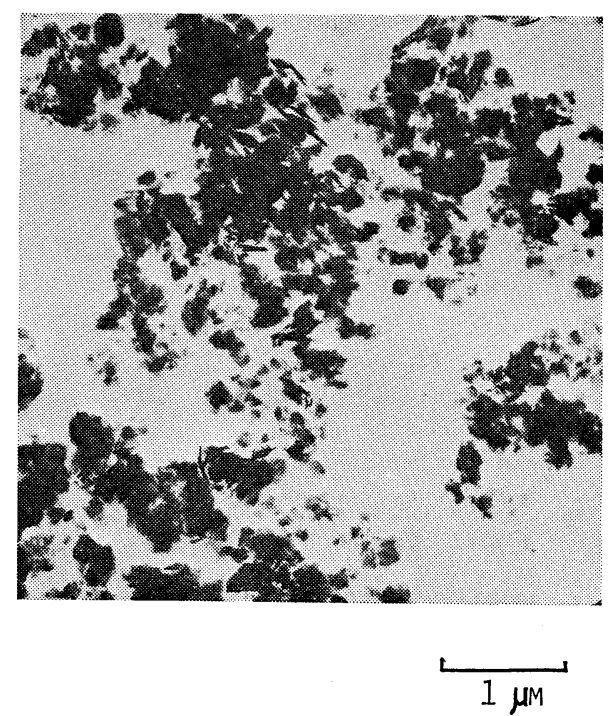

Fig. 12. Electron micrograph of $\mathrm{Co}_{3}\left(\mathrm{PO}_{4}\right)_{2} \cdot 8 \mathrm{H}_{2} \mathrm{O}$ hydrated after grinding

(Grinding time $24 \mathrm{hr}$, hydrating time $24 \mathrm{hr}$ )

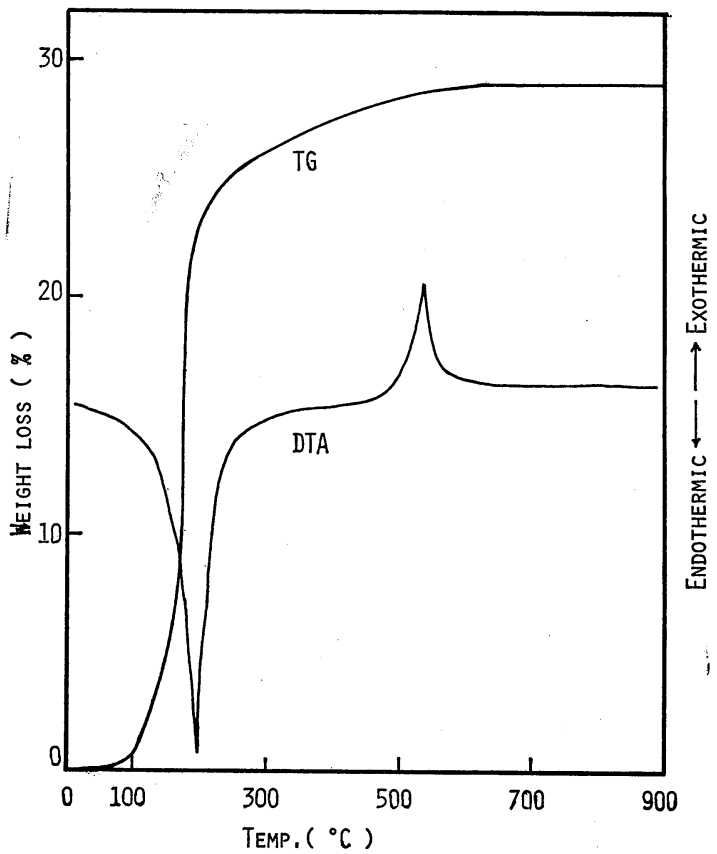

Fig. 13. TG-DTA curve of $\mathrm{Co}_{3}\left(\mathrm{PO}_{4}\right)_{2} \cdot 8 \mathrm{H}_{2} \mathrm{O}$ hydrated after grinding for $20 \mathrm{hr}$ (Heating rate $3.3^{\circ} \mathrm{C} / \mathrm{min}$ )

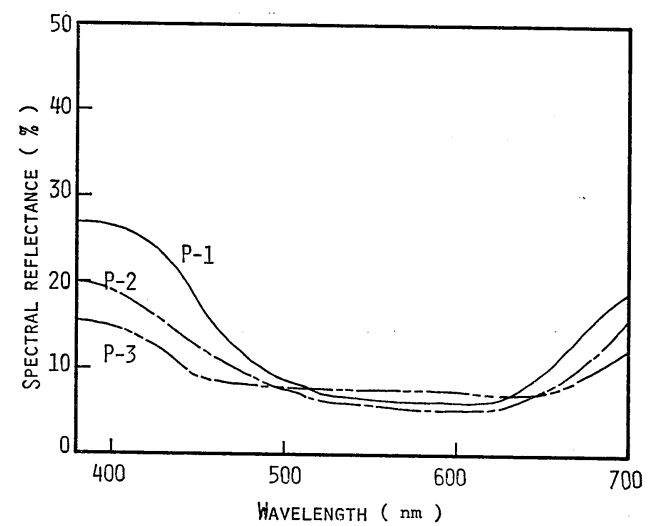

Fig. 14. Spectral reflectance curves of $\mathrm{Co}_{3}\left(\mathrm{PO}_{4}\right) \cdot 8 \mathrm{H}_{2} \mathrm{O}$ heated at $400^{\circ} \mathrm{C}$ $\mathrm{P}-1$ : original, $\mathrm{P}-2$ : ground for $20 \mathrm{hr}$, $\mathrm{P}-3$ : hydrated after grinding for $20 \mathrm{hr}$

Table 2. Colour measurement of $\mathrm{Co}_{3}\left(\mathrm{PO}_{4}\right)_{2}$ heated at $400^{\circ} \mathrm{C}$

\begin{tabular}{c|c|c|c}
\hline Sample & $\lambda d(\mathrm{~nm})$ & $\mathrm{Pe}(\%)$ & $\mathrm{Y}(\%)$ \\
\hline P-1 & -570.0 & 45.5 & 6.6 \\
P-2 & -570.0 & 29.7 & 7.2 \\
P-3 & -566.4 & 14.9 & 4.8 \\
\hline
\end{tabular}


ついて検討した。摩砕物を純水中に入れるとすみやかに 水和して淡紅色の八水和物にもどった。その熱量は 1 時 間摩砕した試料では $13 \mathrm{~J} / \mathrm{m}^{2}, 2$ 時間では $9 \mathrm{~J} / \mathrm{m}^{2}, \quad 5$ 時 間では $11 \mathrm{~J} / \mathrm{m}^{2}, 10$ 時間では $26 \mathrm{~J} / \mathrm{m}^{2}, 20$ 時間では 42 $\mathrm{J} / \mathrm{m}^{2}$ であった。このように, 発生熱量は摩砕時間の長い 試料ほど高くなったが，これは水和熱と結晶化熱による ものと思われる。水和後の粒子形状は, 通常の板状結晶 と異なり微細な不定形粒子になることを認めた(図-12)。 しかも, 水和後の粒子の比表面積は, 摩砕時間の長い試 料ほど大きくなった。たと究ば，2時間摩砕した試料の 水和物では $4 \mathrm{~m}^{2} / \mathrm{g}, 20$ 時間では $18 \mathrm{~m}^{2} / \mathrm{g}$ であった。

図-13 に, 再水和させた八水和物の DTA おょび TG 曲線を示した。DTA 曲線から,この微細な八水和物の吸

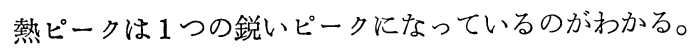

\section{3 粒子形状と色相}

顔料の色は, 粒径, 形状などの粒子性状の違いによっ ても大きく影響をうける。八水和物を $800^{\circ} \mathrm{C}$ で焼成し た紫みのふかい赤紫色の無水物は, 上く知られた顔料 (コバルト・バイオレット・ディープ) であるが，200〜 $500{ }^{\circ} \mathrm{C}$ の範囲では, 紫みのにぶい青紫色となる。この温 度範囲の粒子は, 原試料と外形がほとんど同じである。 そこで, この点に注目して色彩を比較してみた。試料 は, P-1: 八水和物の $400^{\circ} \mathrm{C}, 1$ 時間焼成物 (板状), P2 : 八水和物を 20 時間摩砕したのち, $400^{\circ} \mathrm{C} て ゙ 1$ 時間焼
成したもの (球状), P-3 : 八水和物の 20 時間摩砕物を 水和, 乾燥したのち, $400^{\circ} \mathrm{C} て ゙ 1$ 時間焼成したもの（不 定形状)の 3 種とした。それらの測色結果を図-14 およ び表-2 に示した。各試料とも約 $460 \sim 650 \mathrm{~nm}$ に幅広い 深い吸収を示している(図-14)。P-2 は P-1 と主波長が 同じであるが，球状粒子なので分散性の点では利点があ ると思われる。しかし，摩砕の影響が純度にあらわれて 抢り，P-1 より不鮮明である。一方 P-3 は他に比べて 約 $440 \mathrm{~nm}$ 付近の吸収が強くなり, 主波長 $-566 \mathrm{~nm}$ の 赤みのにぶい青紫色になっている。

（1978 年度化学系 6 学協会大会にて講演）

$$
\text { 文献 }
$$

1）久保輝一郎: “メカノケミストリー概論” 第 2 版, 東京化学同人 (1978)

2) 荒井康夫 : 石高と石灰, 1979 (162), 185.

3) 荒井康夫, 安江 任:工化, 73, 2603 (1970)

4) 荒井康夫, 安江 任:工化, 75, 198 (1972)

5）橋本甲四郎, 戸田善朝：工化，71，1402（1968）

6）伊藤征司郎, 久保好世, 桑原利秀: 色材, 49, 427 (1976)

7）伊藤征司郎, 久保好世, 桑原利秀: 色材, 50, 621 (1977)

8) O.S. DuMont, H. Brokopf, K. Burkhardt: $Z$. Anorg. Allgem. Chem., 295, 7 (1958)

\title{
Mechanochemical Phenomena of Tricobalt Orthophosphate Octahydrate by Grinding
}

\author{
Yoshitomo Toda*, Koshiro Hashimoto* and Yasuo Arai** \\ * Department of Industrial Chemistry, Chiba Institute of Technology. Tsudanuma, \\ Narashino-shi, Chiba-ken 275, Japan \\ ** Department of Industrial Chemistry, Faculty of Science and Engineering, Nihon \\ University. Kanda-Surugadai, Chiyoda-ku, Tokyo 101, Japan
}

Abstract

Mechanochemical phenomena of $\mathrm{Co}_{3}\left(\mathrm{PO}_{4}\right)_{2} \cdot 8 \mathrm{H}_{2} \mathrm{O}$ was studied by grinding.

The crystal of $\mathrm{CO}_{3}\left(\mathrm{PO}_{4}\right)_{2} \cdot 8 \mathrm{H}_{2} \mathrm{O}$ (plates, $3 \times 10 \mu \mathrm{m}$, pink) was converted easily into amorphous phase (bluish violet) as a result of mechanochemical dehydration.

The ground materials were hydrated rapidly in water and recrystallized to fine grain $\mathrm{Co}_{3}\left(\mathrm{PO}_{4}\right)_{2} \cdot 8$ $\mathrm{H}_{2} \mathrm{O}$ (particle size about $0.2 \mu \mathrm{m}$ ).

The temperatures of exothermic DTA peak for crystallization of ground materials were much varied by grind efficiency.

The particle size and hue of pigments were improved by grinding and rehydration of $\mathrm{Co}_{3}\left(\mathrm{PO}_{4}\right)_{2} \cdot 8 \mathrm{H}_{2} \mathrm{O}$. 